\title{
Activity Based Mathematics Instruction: Experiences in Addressing the 21st-Century Skills
}

\author{
Tika Ram Pokhrel \\ Kathmandu University School of Education, Nepal
}

The teaching and learning of mathematics in schools of Nepal is primarily focused on passing the examination. 21st-century skills are the crosscutting skills to be addressed by each subject area. Different games, practical oriented activities, math lab activities, exhibition and projects were designed and implemented in a school in Kathmandu Valley, Nepal. Based on the implementation of these activities, it is observed that mathematics learning through activities is helpful for learning mathematics as well as all-around development of students. Students are engaged in the learning process. They utilize their leisure time with activities. They even invite other individuals to participate in the activity. Apart from learning mathematics, students also learn different skills, such as working in a team, leading group members, communication and presentation, creativity, etc. Thus, these activities are great for learning mathematics as well as other skills required for the 21stcentury.

Keywords: project, game, practical, lab works, 21st-century skills

Mathematics is considered one of the most important subjects in school education in Nepal. School curriculum has set mathematics as one out of five compulsory subjects. Furthermore, there is another mathematics for interested students as an optional subject (Department of Education, Curriculum Development Center [CDC], 2005). Though the Government of Nepal has kept mathematics in a good place in the curriculum, there are challenges in teaching and learning of mathematics in schools.

Students learn Mathematics to pass examinations and teachers focus on making students pass in mathematics or in rare cases, scoring high in examinations. This shows that the teaching and learning process of mathematics is guided by the nature of examinations. In examinations, students are asked to solve algorithmic problems in a paper-pencil test format. Mathematics teaching is mostly for supporting the ability to solve algorithmic problems. These problems are to be done by the method "Do as I have done". This approach to teaching and learning process is creating challenges in the lives of $21^{\text {st }}$-century students. For example, the use of Information and 
Communication Technology (ICT) has challenged the present notion of the teaching and learning process.

It has been realized that students who learn mathematics in any level are to be fit for the modern time. It is mostly reflected that the teaching and learning process of mathematics in Nepal is mostly helpful in preparing for twentieth-century skills. We need to realize that the mathematics curriculum of 1900,1950 or even 1980 cannot prepare the students of today (Kennedy \& Tipps, 2000). This is evidence that this way of teaching and learning mathematics is no more useful than passing the traditional form of examinations. The $21^{\text {st }}$-century skills are to be developed with the perspectives of existing school subjects. These are not the contents kept in the curriculum but can be inbuilt in each of the subjects of the existing curriculum. The major concern of this paper is to share the experiences of a teacher educator in addressing these skills through activity-based instruction in addition to the formal mathematics learning.

Activity Based Mathematics Instruction (ABMI) is guided by the progressive philosophy of education as propounded by John Dewey. This experiential learning focuses on learning by doing. The focus on activitybased instruction can be seen in India in the starting of the century. The National Council of Educational Research and Training [NCERT] (2005) emphasizes that mathematics learning should be facilitated through activities from the very beginning of school education. These activities may involve the use of concrete materials, models, patterns, charts, pictures, posters, games, puzzles and experiments.

\section{Purpose and Research Question}

Activity Based Mathematics Instruction (ABMI) is new to Nepalese context. Certainly, it helps in deepening mathematical understanding and strengthens mathematical skills. It also helps to develop a positive attitude towards mathematics to some extent and students are motivated to do and learn mathematics. The main purpose of the research was to share the experiences on implementing ABMI with reference to the $21^{\text {st }}$-century learning. The research question for the study was "How can the 21st-century skills be addressed in ABMI along with their Mathematics learning?"

\section{Conceptual Framework}

\section{Activity Based Mathematics Instruction}

Activity Based Mathematics Instruction (ABMI) moves beyond the traditional format of lecture and the dogmatic approach of instruction. ABMI is based on the principle of 'learning by doing' as propounded by John Dewey. Learners are actively involved in the process of learning (Marley, Levin, \& Glenberg, 2010, as cited in Aremu \& Salami, 2013) and learning is 
more student-centered. Learning through activity/learning centers, panel discussion, carousel, rehearsal/repetition/practice, debate, retelling, field trips, simulations, games, surveys and oral presentations are activity based strategies (Ministry of Education, 2002). Furthermore, ABMI is based on activity by involving learners in reading, writing, discussion, practical activities, engagement in solving problems, analysis, synthesis, and evaluation (Festus, 2013). Some of the activities as mentioned by Festus (2013) such as discovery approach of teaching, appropriate practical work, use of teaching aids, cooperative learning or small group learning, a discussion in class are linked with ABMI. Activity Based Learning (ABL) also requires active problem-solving in finding patterns in the information through own investigation and analysis (D'souza, 2016). Though there are various strategies in ABMI, games, practical activities, math lab activities and exhibition and project-based learning were selected.

Games are the best means of learning mathematics with fun. Students especially young learners like to play games (Way, 2011). Researches on games show that games are best tools for mental development. Video games improve basic mental abilities: visual process, attention and vigilance, executive functioning and job-related skills (Gray, 2015). Physical games are most powerful not only physical development but also mental as well as psychosocial development. Games are the means for teaching and learning of different objects of mathematics such as games for knowing facts, developing skills, understanding concepts and developing strategy (Kirkby, 1992).

Practical activities are skill oriented approaches in learning mathematics as well as acquiring practical skills. These skills vary according to place and context. Some of the skills are practical calculations, estimation, direction to get a place, etc. Practical activities are related to involvement with physical objects such as measuring length, weight, height, capacity, etc. Practical activities are helpful in gaining firsthand experience. Practical skills can be developed in teaching different areas of mathematics: graphs, transformation, trigonometry, geometry, calculator skills, locus, geometry, etc. (Simpson, 2003).

Mathematics laboratory [in short Math lab] is a place; generally, a classroom in the school, where students can experiment and explore patterns and ideas (Homi Bhabha Centre for Science Education, n. d.). Different activities are done to explore and verify mathematical relations with the help of games, puzzles and other special materials. Generally, Math lab is used to explore and test mathematical idea informally. Paper cutting and folding are also used as lab activities on verifying mathematical concepts in a very much concrete way (Upadhyaya, 2002). This place can be best utilized for discovery or guided discovery learning. Students also develop different models to represent mathematical objects and relations. The exhibition is one of the program students organize to share their idea, work, etc. This can be done by 
students group and teachers, to other groups of students and other interested individuals.

Learning mathematics through projects brings life to the school atmosphere (Sidhu, 1995). In the same thought, "Developing the capacity to think and work mathematically requires students engage in a range of tasks, problems, and investigation" (Schoenfeld, 1992, as cited in Zevenbergen, Dole \& Wright, 2005, p. 106). A plan to complete series of tasks is simply project and learning by completing the tasks is project-based learning. Furthermore, a project is a wholehearted purposeful activity proceeding in a social environment (Kilpartick, as cited in Kochhar, 1985). Thus, a project is the set of activities having educational value and aimed at one or more definite goals of understanding. It involves investigation and solution of problems and frequently the use and manipulation of physical materials, planned and carried to completion by pupils and teacher in a natural like manner (Good, as cited in Jha, 1995).

\section{Twenty-First Century Skills}

Everyone knows that schools prepare students for the future, which is challenging for everyone in the 21 st-century. It is time to critically review the challenges demanded by the twenty-first century. There is another concern of education, whether our education prepares to challenge to the different skills. Schools need to prepare students right from the present and so that students can shape their future themselves. There is variation in stating the skills required for the 21 st-century. The variation in the 21 st-century skills is due to perspective and context of requirements of these skills.

The role of education in the 21st-century is to be different and education should foster: flexibility, creativity, problem-solving ability, technological literacy, information-finding skills, and above all lifelong readiness to learn (Macdonald \& Hursh, 2006). National Council of Teachers of Mathematics [NCTM] process standards: problem-solving, reasoning and proof, communication, representation, and connection, etc. are linked with the 21 st-century skills. These skills are not the contents of the school curriculum and are to be addressed by any subject especially with mathematics. But these 21st-century skills are to be explicitly integrated into standards, assessment, curriculum, instruction, professional development and learning environment (Partnership for 21st-century Skills, n. d.). It further mentions that the $21 \mathrm{st}-$ century skills are required to solve problems that have not been solved before. Such activities related to ABMI can be finding proofs, puzzling, understanding patterns and finding meaning in statistics. These skills are developed in the learning process as well as helpful in learning different subjects.

The demand of new century requires that all students acquire an understanding of concepts, proficiency with skills and a positive attitude in mathematics if they are to be successful (Kennedy \& Tipps, 2000). The skills 
we look in mathematics are practical such as communication, ICT, learning, investigation and reasoning skills (Simpson, 2003). The process standards extend thinking/learning skills: problem-solving, reasoning and proof, communication, mathematical representation and connections (Kennedy \& Tipps, 2000).

Based on above discussion, ABMI consists of different activities including games, practical activities, math lab activities, exhibition, project work, etc. Critical thinking, problem solving, communication, collaboration, creativity, leadership skills are some of the examples of the 21 st-century skills. Figure 1 is the summary of the conceptual framework developed for the present paper:

\begin{tabular}{|c|c|c|c|c|}
\hline Games & \multirow{4}{*}{ 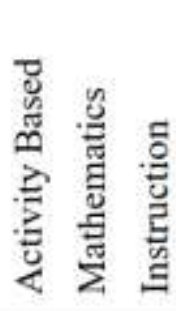 } & & \multirow{4}{*}{ 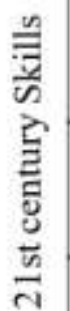 } & \multirow{2}{*}{$\begin{array}{l}\text { Critical thinkng and } \\
\text { Problem solving }\end{array}$} \\
\hline Practical activities & & & & \\
\hline Mathlab and Exhibition & & & & $\begin{array}{l}\text { Communication and } \\
\text { Collaboration }\end{array}$ \\
\hline Project work, ... & & & & Creativity, ... \\
\hline
\end{tabular}

Figure 1. Conceptual framework.

This may be a challenging task for educators to show how the $21^{\text {st }}$ century skills can be developed through mathematics lessons. How to integrate these skills in the mathematics lessons is one end of the problem and how these planned activities are helpful in developing the $21^{\text {st }}$-century mathematical skills in students can be another end of the problem. This paper tries to share the experiences of an educator in designing and implementing activity-based mathematics instruction with a view to use and develop the 21 st-century skills in addition to formal mathematics learning as intended by the curriculum.

\section{Methods}

The study was based on the qualitative research method and mainly in teaching experiment within interpretive research paradigm. This shows that the experience of the author shared in the paper is based on the research process and reflections of various stakeholders.

\section{Interpretive Research Paradigm}

An Interpretivist is committed to understanding social phenomena from the actor's own perspective and examining how the world is experienced (Taylor \& Bogdan, 1998), the author tried to understand classroom practices from participants' perspective and examine their experiences. The researcher 
believed in the construction of meaning during the research process as guided by 'transactional/subjective' (Guba \& Lincoln, 1994) knowledge construction. In interpretive approach, the researcher tries to elucidate the process of meaning construction and clarify what and how meanings are embodied in language and action of social actors (Schwandt, 1994). The researcher tried to be in the position of ontological relativism (Guba \& Lincoln, 1994) during the research process. The reality was based on the construction of an individual(s) in his/her local or specific context and is contextual and may be multiple. The researcher valued on each individual that each as unique in understanding in his/her way.

\section{Designing Activities in ABMI}

The researcher started to work from teaching experiment as a method of study. Because "It is based on the conceptual analysis rather the subjects in the experiment are recipients of the treatment" (Hajra, 2013, p. 8). This research was carried with a view to understanding the process and progress made by the students. The teaching experiment is directed toward understanding the progress students make over extended periods (Steffe \& Thompson, 2000). Moreover, design experiment has been extensively used in teaching experiment because of its pragmatic and theoretical orientation (Cobb, Confrey, DiSessa, Lehar, \& Schauble, 2003). First, the researcher selected a theme. Then there were several other related themes for the selected themes to be dealt together. Second, objectives and time requirements were determined. Third, different resources were explored considering questions: Who are the participants, what materials are required, what facilities are needed to conduct the activity. Fourth, activities like games, project, worksheet, etc. were designed and a sequence of a plan was prepared. Fifth, review and finalization were done for implementation.

\section{Research Site and Participants}

A school of the Kathmandu Valley, Nepal, was selected to carry out the experiments. The variation across the grades was tried with a view to capturing different essence in learning mathematics and skills in different age groups. A total of 33 days of 45 minutes each was spent in implementing ABMI in different grades from grades one to 10 by the researcher, where classroom teacher was also supported in the activities (see Appendix A). After each class, one-two students were selected for a short 5-10 minute reflection interview. A total of 25 students were interviewed in the process. In addition to this, a full day was utilized in observing and interacting with the students in project exhibition day.

\section{Data Collection and Analysis}

The observation of the teaching and learning process was the major evidence. Later the researcher narrated those observations in the reflective 
notes. One or two students were interviewed after each class with reference to the day's activity and to get their reflection about the learnings. Questions were related to learning activities. What did you learn best? What your friends learned best? Why do you think today's learning is important? What do you expect in next class? What was not clear to you? These are some of the questions asked in the interview. Some of the worksheets and works of the students were also captured in the form of photos. Later these themes were classified according to learning strategies as games, practical activities, math lab activities and projects.

\section{Observation and Discussion}

This section depicts the learning of students with reference to observation and reflection of students, teachers and the researcher. Noticed observations and remarks given by students are grouped here in line with the category of activities: games, practical activities, math lab activities and exhibition and project work.

\section{Games}

The experience of using games in learning school mathematics with reference to some games is presented here.

Who can Count First? The rule of the game was "The group who counts all the toothpicks correctly at first will be the winner". Students in playing this game for a day of forty-five minute, demonstrated how to use a rubber band to group and count later. All they applied the techniques of grouping by 10 and they really enjoyed. Collaboration was noticed in their group work. It is helpful to realize the necessity of grouping. The game is best for developing collaborative strategy and helpful in developing number sense.

How Many at My Back? The game "how many at my back?" is a thinking game and it looks like magic to find how many are at the back without counting them. Put certain number, for example, twelve marbles on a table and a student catches a number of them without showing to others and put at his/her back. Another student needs to find out how many at the back. In using this game, students first guessed the numbers, but later they found the rule of subtraction. It is experienced that students play with more interest till they find the rule. After they found the rule they were less interested in being player. This game was helpful in developing a rule based on the inverse relation.

Who Makes Jogi [Bankrupt]? It is a card game played with 40 playing cards to practice multiplication facts in young learners. The picture cards J, Q, and $\mathrm{K}$ were removed and Ace was considered as one. Then asked students to be in two pairs (4 students in a group) sitting opposite. One distributed all 40 cards equally to 4 players. Each player started to show one card randomly and asked to find the product of the values of partners. The pair 
having greater value wins the cards and captures. The pair having captured all cards wins the game. Based on the reflection of the game, students enjoyed a lot in playing the game and it was helpful in learning multiplication facts. This game is a practice game designed with a view to seeing its effect. But still, it is our common consensus to make students mastery in multiplication facts.

Salute Game. The Salute game is also played with a group of 4 students with 40 cards numbered from 1 to 10 . Two players play, one announcer and another works as a referee. Both the players sit opposite to each other and pick one card each from the pack without looking its value and puts on the forehead so that the opposite friend can see it. When both the players put the cards on their foreheads, the announcer says the product of the cards, then each of the players need to recognize the value of their card first. The player who recognized first collects both cards. The referee decides whether the recognition is correctly done or not. The player having the greater number of cards wins the game. The game was interesting to students and they started playing in the other time and even at home.

Frango. Playing bingo is very much popular in our context. Based on the rules of bingo, a game named Frango was designed to teach the addition of simple fractions. It was informed to bring Rs. 5 to play a game Frango in earlier day. The next day, two fractions were announced and they had to add and color where the sum of fractions appeared. There were several options for each row, column, diagonal and full house. It was noticed that everyone enjoyed playing Frango. It was planned for the students to play themselves so that they add and learn independently. It became one of the practice games to add fractions. Students seem busy in addition and checking the sum with each other. A type of consultation among friends was noticed. They themselves were divided into small groups.

Stepping Steps. Four games were developed to teach four operations of integers by considering 'game for knowing facts, developing skills, understanding concepts and developing strategy' (Kirkby, 1992) in composite form. The four games: AddInt, SubInt, Mullint and DivInt were developed to represent operations: addition, subtraction, multiplication, and division of integers. The rules of the games were developed as the rules of integers. From the game, students learned rules of the games with a view to winning the game. They developed a strategy to play the game to make their group win. It was quite easy to observe the students who were not performing as the rule of the game. They communicated the commands quickly and clearly. They tried to build team and leadership roles in engaging team members play and win. A worksheet was also developed for giving problems to be solved and instructed the reference to the game. It was wonderful work by the students after the game.

Straight Line Game. To teach the concept of coordinate system, a game was designed using graph board and two dice of different colors. This game was played between two players. They, in turn, throw both dice and 
marked the numbers in each of the dice and made a coordinate point and put a mark on the graph board. The player who first makes three marks in a straight line is the winner. The rule was helpful to teach the test of collinearity. Some of the students, while testing collinearity, used thread to check whether they are collinear or not. Some of them also used ruler or straightedge. This made them think differently for checking three of their points in a straight line. This is helpful in developing creativity and imagination.

Flips, Slides, and Turns. It was searched on the internet and found a game called "Flips, Slides, and Turns". We asked students to prepare two congruent shapes of our National flag, which is in a triangular shape and played the game in pairs. We realized that students developed the concept of translation, rotation, and reflection in an easy way.

Magic Height. A game to find the height of a person without direct measuring was given to each of the group as a game. They used clinometer developed by themselves with a protractor to find the angle of elevation. The group who could find at first accurately average height of the group was declared the winner. This was the game to secondary level students and it integrated mean and height and distance. Also, they learned to be evidencebased. They presented their records and calculation of the average height of their group.

Center of Circle. In finding the center of a circle, each group of students was assigned to a circle drawn on the ground without a center. They had to find the center of the circle. The group who found the center at first correctly was the winner. This game helped to use properties of a circle. Students applied different strategies to find the center.

\section{Practical Skills-Oriented Activities}

Practical skills-oriented activities were designed with a view to link mathematics to their daily lives. Some of the activities that were implemented during the study are discussed below:

Counting Money. To develop number sense and counting skills in a practical way, students were given an amount of Nepali Rupees (Rs.) 368 with 1 note of Rs. 100, 8 notes of Rs. 10 and all other of Re 1 coins. There was an exchange box if they require. They started counting money in their groups and different strategies were applied by different groups. One group used grouping and separation money with reference to value. Another group used counting by all members and adding themselves orally. This experiment helped the learners make meaning on practical learning. Learning though practical activities was not only helpful in sound understanding of mathematical concepts and applications but also helpful in developing different 21 st-century skills. This activity reflected to express the importance to context. Students bring context to their learning and is helpful in fostering creativity and imagination. Students value the diversity. Different life skills including social skills are addressed through the approach. 
Measuring Body Parts. Measurement is another challenging skill among most of the students. Measuring and knowing their own heights and length of different body parts was another activity organized in grade six. From the activity, it was noticed that students like to know about their body. They compare with their friends' information. This activity was helpful to make them to think about their body part. Some health related discussions were also made like height in 11 years, length of hands and fingers and many others. They explored health relations and discussion of health issues was another great learning through measurement activity.

Cutting and Eating Apples. An example of practical activity is to give concept of fraction and its types with cutting apples into different parts and asking them to distribute and eat different parts. By cutting apples, distributing, and eating certain parts, students learned addition and subtraction of fractions. It was a fun activity with sharing their apples to others and collecting from others. This was helpful in understanding fractions. It helped in communication and socialization.

Shopping in School. Students of grade seven (12 years) established a shop in the school for a day and named it as Shop Today in School. There were ten groups consisting of three to four in a group. There was an announcement in earlier day about the shop in school. They used selfdeveloped billing. They collected money among themselves and bought goods themselves going into the wholesalers. They sold different objects to students of other grades. All the groups made profits. From the observation of activity, the researcher noticed that students were engaged in negotiation. It was helpful in developing convincing skills with good communication and presentation. It was a simulation for preparing life skills. Next day, they shared their experience on buying and selling goods in school. The sharing was wonderful that they developed strong relationship with everyone including researcher.

Role Play on Profit and Loss. Students of grade IX were asked to prepare a role-play of shopping including the calculation of profit or loss percentage. They were divided themselves into different groups consisting of 4-7 members. They were also asked to prepare a video clip of their role plays. A week time was given to prepare it. After a week, each group showed their drama/role play in their classroom. From this activity, students learned to calculate profit or loss percentage as well as they were creative in role play and actively collaborated in the role play.

\section{Math Lab Activities and Exhibition}

Five Math Lab activities were implemented on different grades with a view to explore how students develop skills of conjecturing formulae on area of plane figures and solids. Students of grade five worked to find the area of rectangle as length $\mathrm{x}$ breadth by using unit squares. Students of grade six were busy in finding formula to calculate area of triangle. They tried many 
ways to find the formula. The guided learning approach was used to convert triangle to rectangle with the same base. When one of the groups discovered that it is of half height, they were so excited on discovering new thing. They themselves distributed to each group to share their way. Though the lab work was designed for a period of 45 minutes, it was extended to another period of 45 minutes with a view to work with their passion of conjecturing and sharing with each other. Similarly, students of grade nine and 10 worked out in finding formulae of area of circle and sphere. In finding area of circle, they cut a circle into 16 pieces and joined so that it was converted into rectangle. In finding the surface area of sphere, they used oranges and used it to cover the pave circles.

Learning in mathematics laboratory was helpful for understanding and internalizing the basic mathematical concepts through concrete situations. It widens the experimental base and prepares the ground for better learning of new areas in the subject. An activity involves both the mind and hands of the student working together, which facilitates cognition. It lays down a sound base for more abstract thinking (Central Board of Secondary Education, 2015).

Further, it provided concrete form for abstract mathematical relations. Abstract mathematical relations were conceptualized based on concrete materials as models. Students learn to generalize mathematical relations based on concrete materials. Math Lab activities made them to think mathematically and was helpful in testing relations.

Exhibition was organized to share learning among students. A total of 16 selected works was exhibited by students from grade six to nine in a day. Around 200 visitors visited their stalls and they shared their works to other stakeholders like teachers, parents, etc. In exhibition students presented their works actively as sharing their learning with other. Students learned to take turn and present mathematical idea in simple form. It is an opportunity for them to develop social and communication skills.

\section{Project Work}

Project in learning mathematics is another dimension to see learning by doing. Assigning a sequence of task is very important way to give project work to students. Students visited themselves in different shops to find out their cost price, selling price, profit and loss. This is an integrated project which consists of several tasks. The learning of students in integrated project encouraged them to think critically about the loss. Learning was based on what they had done. Students presented their project in the classroom. Inquiry with shopkeepers and presentations in the classroom are some of the obvious 21 st-century skills developed through the project in addition to learning about profit and loss experientially.

Another project on developing models was helpful in fostering thinking skills. Students prepared small model houses and recorded the 
amount of money required for painting the model houses. Based on the calculation of cost of painting a model house students projected the cost to a given house. This type of mathematical activity is helpful for mathematical thinking. In this activity, students prepared a plan for painting the model house, planning included sequential work to be done, color choice, cost estimation, buying colors, painting and calculating actual cost. It is helpful in developing generalization skills and reasoning skills.

This learning from ABMI can also be reflected from MOE Singapore (2013) that in activity-based lessons, students are better engaged, learn better, and develop a positive attitude towards their learning. Apart from learning mathematics students learn different 21 st-century skills such as working in teams, leading group members, communication, presentation, creativity, etc. It is linked with activity-based learning builds self-confidence, creates opportunity for social relations with different age groups, and provides varied experiences and values in learning (D'souza, 2016). Thus, activities provide opportunities for leaning mathematics as well as other skills required for the 21st-century. Furthermore, ABMI is a progressive and developmental approach to learning because it is exploratory, constructive and expressional (D'souza, 2016).

\section{Reflection and Implication}

ABMI is helpful in mathematics learning in a meaningful and enjoyable way. Students are able to visualize mathematics to their context in the learning process. Games are helpful in developing team building and leadership activities. In the Who Can Count First game, students demonstrated some of the collaborative skills apart from the learning of counting and grouping of numbers. Students tried to find rules for subtraction as the inverse of addition while playing the game How Many at My Back. After playing the game Who Makes Jogi in the classroom, students continued to play at home. This is an example of self-initiation in learning at home and in other places. Similarly, the game Stepping Steps was helpful in developing strategies for their team. In this game, students tried to build team and leadership roles in engaging team members to play and win. Students can develop diverse approaches in testing a mathematical property. For example, in playing Straight Line Game some of the students, to test collinearity, used thread to check whether they were collinear or not. Some of them also used a ruler or straightedge. This made them think differently for checking three of their points in a straight line. This is helpful in developing creativity and imagination.

In playing games, students learn the rules of the game, rather as the rule of the problem. Everyone gets high concentration in using rules to win games. They play games with friends and with their team, as a result if one is making a mistake another member immediately corrects him/her. Though they 
know that games are about the mathematics, they think that they can play games and win the games. Thus, based on the experience gained in implementing games, the findings of the study indicate that games can make students more engaged in learning and learning is more joyful and fun. In Nepalese culture, the phenomenon of playing cards is directly perceived as negative. However, some of the games were played by using playing cards. We were worried about the negativity of using cards in the school and the perception of parents regarding cards. It was exciting to hear from parents that some of the students started to teach their parents about the game and parents also played with their kids.

Students related practical skills-oriented activities as real learning. They considered these activities as happening in their lives. For example, in counting money, they learned how to group numbers, and how to work in their group. They also developed a strategy for working in their group. Measuring body parts, they linked their measurement data with health issues. Thus, learning though practical activities was not only helpful in sound understanding of mathematical concepts and applications but also helpful in developing different 21st-century skills. Practical activities are helpful in developing social and life skills and creativity and imagination. They also showed their interest in bringing social issues in the mathematical learning as they did in a role play of profit and loss.

Math lab based activities were helpful in generating abstract mathematical concepts and relations through direct objects. Lab based activities were helpful in making students think mathematically and were helpful in testing relations. Through exhibition, students were given the opportunity to develop social and communication skills. Projects were helpful in problem-solving, communication, and presentation skills.

Finally, making mathematics learning activity-based is helpful in the all-around development of students. Students are engaged in the learning process. They utilize their leisure times with activities. They even invite other individuals to participate in the activity. Students show interest in learning mathematics.

\section{References}

Central Board of Secondary Education. (2015). Guidelines for mathematics laboratories in schools (Grade IX). New Delhi: India: Author.

Chou, Y. K. (26. February 2014). Gamification to improve our world. Retrieved from https://www.youtube.com/watch?v=v5Qjuegtiyc.

Cobb, P., Confrey, J., DiSessa, A., Lehar, R., \& Schauble, L. (2003). Design experiments in educational research. Educational Researcher, XXXII(I), 9-13. 
Constructivist teaching methods. (2016). Retrieved from

http://ccti.colfinder.org/sites/default/files/constructivist_teaching_meth ods.pdf.

Department of Education, Curriculum Development Center [CDC]. (2005). National Curriculum Framework. Sanothimi, Bhaktapur: Nepal: Author.

D'souza, Q. (19. March 2016). Activity Based Learning. Retrieved from https://www.youtube.com/watch?v=eCXHVTcAS7k.

Festus, A. B. (2013). Activity-based learning strategies in the Mathematics classroom. Journal of Education and Practice, 8-14. Retrieved fromwww.iiste.org/Journals/index.php/JEP/article/download/6768/688

Gray, P. (20. February 2015). Psychology Today. Cognitive benefits of playing video games. Retrieved from https://www.psychologytoday. com/ blog/freedom-learn/201502/cognitive-benefits-playing-videogames.

Hajra, S. G. (2013). Teaching experiment and its role in teaching.

Johansson, A. W., \& Lindhult, E. (2008). Emancipation or workability?: Critical versus pragmatic scientific orientation in action research. Action Research, 6(1), 95-115. doi: 10.1177/1476750307083713.

Kapp, K. M. (13. May 2014). What is gamification? A few idea. Retrieved from https://www.youtube.com/watch?v=BqyvUvxOx0M\&t=16s.

Kennedy, L. M., \& Tipps, S. (2000). Guiding children learning of mathematics (9th Ausg.). Wadsworth Thomson Learning.

Kennedy, 1. M., \& Tipps, S. (2000). Guiding children's learning of mathematics. Australia: Wadsworth: Thomson Learning.

Kirby, D. (1992). Games in the teaching of mathematics. Cambridge University Press.

Kirkby, D. (1992). Games: In the teaching if mathematics. Cambridge University Press.

Kumar, J. (12. January 2015). Youtube TEDx Graz. Retrieved from https://www.youtube.com/watch? v=6wk4dkY-rV0.

Macdonald, G., \& Hursh, D. (2006). Twenty-first century school: Knowledge, network and new economies. Rotterdam/Taipei: Sense Publishers.

Macdonald, G., \& Hursh, D. (2006). Twenty-first century school: Knowledge, network and new economies. Rotterdam/Taipei: Sense Publishers.

McIntyre, A. (2008). Participatory action research. Sage Publications.

MOE Singapore. (05. March 2013). Fun \& Activity-Based Mathematics. Retrieved from https://www.youtube.com/watch?v=Tp2nqf4A-XE.

National Council of Educational Research and Training (NCCERT). (2005). National Curriculum Framework. Retrieved from http://www.ncert. nic.in/rightside/links/pdf/framework/english/nf2005.pdf.

Partnership for 21st-century Skills. (n. d.). P21 Common Core Toolkit: A guide to aligning the common core state standards with the framework 
for 21st-century skills. Abgerufen am 30. Retrieved from www.P21.org.

Pokhrel, T. R. (2015). Activity based mathematics instruction. Second National Conference on Mathematics Education (S. 25-29). Pokhara, Kaski, Nepal: Council for Mathematics Education.

Rathva, P. (2012). Teaching mathematics through activities. Retrieved from http://www.ncert.nic.in/pdf_files/teaching\%20mathematics(Parul\%20 Rathva).pdf.

Simpson, A. (2003). Teaching and assessing skills in mathematics. The Edinburgh Building, Cambridge, UK: Cambridge University Press.

Steffe, L. P., \& Thompson, P. W. (2000). Teaching experiment methodology: Underlying principles and essential elements. In R. Lesh, \& A. E. Kelly, Research design in mathematics and science education (S. 267307). Hillsdale, NJ: Erlbaum.

Upadhyaya, H. N. (2002). Folding and cutting of papers in the teaching mathematics. Kathmandu: Ekta Books Distributers Pvt Ltd.

Way, J. (February 2011). Learning mathematics through games. Retrieved from https://nrich.maths.org/2489. 
Appendix A

Distribution of Activities in Mathematics Instruction

\begin{tabular}{|c|c|c|c|c|c|}
\hline $\begin{array}{l}\text { Type of } \\
\text { activity }\end{array}$ & Area of content & Activity named & $\begin{array}{l}\text { Grade } \\
\text { (Age) }\end{array}$ & $\begin{array}{l}\text { Days } \\
\text { spent }\end{array}$ & $\begin{array}{l}\text { \#of } \\
\text { Students } \\
\text { interviewed }\end{array}$ \\
\hline \multirow[t]{10}{*}{ Game } & Addition & Who can count first? & $2(7)$ & 1 & 1 \\
\hline & Subtraction & $\begin{array}{l}\text { How many at my } \\
\text { back? }\end{array}$ & $1(6)$ & 1 & 0 \\
\hline & Multiplication & Who Makes Jogi? & $3(8)$ & 1 & 1 \\
\hline & Multiplication & Salute & $\begin{array}{l}3-5(8- \\
10)\end{array}$ & 1 & 3 \\
\hline & Fraction (Add) & Frango & $5(10)$ & 1 & 1 \\
\hline & Integer & Stepping steps & $5(10)$ & 5 & 2 \\
\hline & Coordinate & Straight Line Game & $6(11)$ & 1 & 1 \\
\hline & $\begin{array}{l}\text { Geometric } \\
\text { Transformation }\end{array}$ & Flips, Slides and Turns & $8(13)$ & 1 & 1 \\
\hline & $\begin{array}{l}\begin{array}{l}\text { Height } \\
\text { distance }\end{array} \\
\end{array}$ & Magic Height & $10(15)$ & 2 & 1 \\
\hline & $\begin{array}{l}\text { Properties of } \\
\text { Circle }\end{array}$ & Center of Circle & $10(15)$ & 1 & 1 \\
\hline \multirow{5}{*}{$\begin{array}{l}\text { Practical } \\
\text { activity }\end{array}$} & Number Sense & Counting money & $3(8)$ & 2 & 1 \\
\hline & Subtraction & Measuring body parts & $6(11)$ & 2 & 1 \\
\hline & Fraction & $\begin{array}{l}\text { Cutting and eating } \\
\text { apples }\end{array}$ & 2(6) & 2 & 1 \\
\hline & Profit and Loss & Shopping in school & $7(12)$ & 3 & 3 \\
\hline & Profit and Loss & Role Play & $7(12)$ & 3 & 2 \\
\hline \multirow[t]{5}{*}{$\begin{array}{l}\text { Lab } \\
\text { work }\end{array}$} & Area of circle & $\begin{array}{l}\text { Formula for finding } \\
\text { area of circle }\end{array}$ & $\begin{array}{l}9(14), \\
10(15)\end{array}$ & 2 & 1 \\
\hline & $\begin{array}{l}\text { Surface area of } \\
\text { sphere }\end{array}$ & $\begin{array}{l}\text { Formula for finding } \\
\text { surface area of sphere } \\
\text { (orange) }\end{array}$ & $10(15)$ & 1 & 1 \\
\hline & $\begin{array}{l}\text { Angles of a } \\
\text { triangle }\end{array}$ & $\begin{array}{l}\text { Sum of interior angles } \\
\text { of a triangle }\end{array}$ & $8(13)$ & 1 & 1 \\
\hline & Area of triangle & $\begin{array}{ll}\text { Formula } & \text { for } \\
\text { calculating } \\
\text { triangle }\end{array}$ & $7(12)$ & 1 & 1 \\
\hline & $\begin{array}{l}\text { Area of } \\
\text { rectangle }\end{array}$ & $\begin{array}{ll}\begin{array}{l}\text { Formula } \\
\text { calculating } \\
\text { rectangle }\end{array} & \text { area } \\
\end{array}$ & $6(11)$ & 1 & 1 \\
\hline
\end{tabular}

\section{Author:}

Tika Ram Pokhrel

Kathmandu University School of Education, Nepal

Email:trp@kusoed.edu.np 